\title{
PENGARUH PENGGUNAAN METODE PEMBELAJARAN DAN PENILAIAN AUTENTIK TERHADAP KEMAMPUAN REPRESENTASI MATEMATIS SISWA
}

\author{
Jafar Dahlan \\ Universitas Bumi Hijrah \\ Maluku Utara \\ Yuliatri Sastrawijaya \\ Fakultas Teknik Universitas Negeri \\ Jakarta \\ DKI Jakarta
}

\begin{abstract}
This study was conducted at SMPN 5 and SMPN 8 Kota Tidore Kepulauan. The research method used is experimental method, while the study is done by using factorial $2 \times 2$ design. Samples were selected by using simple random sampling technique. The samples of this research are 84 students of $8^{\text {th }}$ grade of the second semester of the 2015/2016 academic year. Data collection was done by measuring the ability of a mathematical representation of students. The hypothesis was tested by using analysis of variance (ANOVA). The results showed that there are positive implications between the methods of learning and authentic assessment to the students' ability in mathematical representation.
\end{abstract}

\section{Keywords}

Representation of mathematical ability, learning method, authentic assessment

\begin{abstract}
ABSTRAK
Penelitian ini dilakukan di SMPN 5 dan SMPN 8 Kota Tidore Kepulauan. Metode yang digunakan adalah metode eksperimen, sedangkan desain yang digunakan adalah faktorial $2 \times 2$. Sampel diambil menggunakan teknik simple random sampling. Sampel penilitian ini adalah 84 siswa SMP kelas VIII semester genap pada tahun pelajaran 2015/2016. Pengumpulan data dilakukan dengan mengukur kemampuan representasi matematis siswa. Hipotesis penelitian diuji dengan menggunakan analisis varian (ANAVA) dua jalan. Hasil penelitian menunjukkan bahwa terdapat implikasi positif antara metode pembelajaran dan penilaian autentik terhadap kemampuan representasi matematis siswa.
\end{abstract}

Kata Kunci

Kemampuan Representasi matematis, metode pembelajaran, penilaian autentik.

\section{Pendahuluan}

Peningkatan kualitas pendidikan khususnya dalam mata pelajaran Matematika merupakan hal yang sangat strategis untuk menyiapkan sumber daya manusia yang berkualitas dan memiliki kompetensi dalam pengetahuan dan teknologi, hal ini diperoleh jika seluruh aspek yang terkait dengan proses pembelajaran dilaksanakan secara optimal. Namun kenyataannya, perkembangan pembelajaran matematika di Indonesia masih sangat jauh dari harapan. Berdasarkan hasil penelitian yang dirilis pada bulan Januari 2013 oleh Programme for International Student Assessmen (PISA), bahwa dari 65 negara yang mengikuti event tersebut Indonesia menduduki peringkat ke 63. Demikian juga hasil dari Trends in Mathematics and Science Study (TIMSS) tahun 201I yang pesertanya siswa Indonesia kelas VIII. Penilaian yang dilakukan International association for the evaluation of educational achievement study center boston college tersebut diikuti 63 negara. Untuk mata pelajaran Matematika, Indonesia menempati urutan ke-38 dengan skor 386. Skor Indonesia ini mengalami penurunan II angka dari penilaian tahun 2007.

Fakta di lapangan membuktikan bahwa seringkali dalam pembelajaran matematika di sekolah, siswa hanya menghafal konsep dan kurang mampu menggunakan konsep tersebut jika menemui masalah dalam kehidupan nyata yang berhubungan dengan konsep yang dimiliki. Sebagian besar siswa kurang mampu menghubungkan antara apa yang mereka pelajari dengan bagaimana pengetahuan tersebut akan dimanfaatkan atau diaplikasikan pada situasi baru, hal ini berdasarkan hasil wawancara dengan guru mata pelajaran di SMPN 5 dan SMPN 8 Kota Tidore Kepulauan. 
Salah satu keterampilan proses yang penting namun kurang dikuasai siswa, yaitu: kemampuan representasi matematis. Siswa masih mengalami beberapa kesulitan dalam menyelesaikan soal terkait menuliskan masalah kehidupan sehari-hari ke dalam bentuk model matematika, menghubungkan antar obyek dan konsep dalam matematika, dan dalam menentukan rumus apa yang akan dipakai jika dihadapkan pada soal-soal yang berkaitan dengan masalah kehidupan seharihari. Selain itu, siswa juga mengalami kesulitan dalam menghubungkan antar konsep yang sebelumnya telah diketahui oleh siswa dengan konsep baru yang akan siswa pelajari, karena dasar-dasar berpikir belum dikuasai dengan baik.

Kemampuan representasi matematis sangat penting untuk dimiliki siswa agar siswa mampu membuat suatu hubungan yang bermakna antar konsep matematika atau antara konsep dengan bidang lain ataupun dengan kehidupan atau lingkungan sekitar siswa. Representasi matematis siswa adalah merupakan ungkapan-ungkapan dari gagasan-gagasan atau ide-ide matematika yang dapat menggambarkan, mewakili, atau melambangkan sesuatu yang ditampilkan siswa dalam upaya untuk memahami suatu konsep matematika guna mencari solusi dari masalah yang sedang dihadapinya (Hutagaol, 20I3; Bal, 20I5). Representasi ini sangat berperan dalam upaya mengembangkan dan mengoptimalkan kemampuan matematika siswa.

Berdasarkan fakta-fakta di atas maka sudah saatnya guru menerapkan paradigma baru dalam proses pembelajaran matematika di kelas, di mana pembelajaran matematika tidak sekedar menyampaikan berbagai informasi seperti definisi, aturan, dan prosedur untuk dihafal oleh siswa tetapi guru harus melibatkan siswa secara aktif dalam proses belajar mengajar (Kartini, 2009). Salah satu pembelajaran yang dapat membuat siswa aktif dan mengkonstruksi pengetahuannya adalah dengan menggunakan metode penemuan terbimbing. Belajar dengan metode penemuan sesuai dengan pencarian pengetahuan secara aktif oleh manusia, di mana siswa berusaha sendiri untuk mencari pemecahan masalah serta pengetahuan yang menyertainya, siswa dituntut menemukan sendiri hal baru yang berupa konsep, prinsip, prosedur, algoritma, dan semacamnya yang dipelajari siswa (Effendi, 2012; Hasibuan,
20I4). Penemuan yang dimaksud, yaitu: siswa menemukan konsep melalui bimbingan dan arahan dari guru karena pada umumnya sebagian besar siswa masih membutuhkan konsep dasar untuk dapat menemukan sesuatu. Menurut (Eggen dan Kauchak, 2012; Jacobsen, 2009) metode penemuan terbimbing adalah satu pendekatan mengajar yang dirancang oleh guru untuk memberi siswa contoh-contoh topik/konsep spesifik dan memandu siswa untuk memahami topik/konsep tersebut. Selanjutnya, Jacobsen mengatakan bahwa ketika menggunakan strategi ini, guru menyajikan contoh-contoh pada siswa, memandu mereka saat mereka berusaha menemukan pola-pola dalam contoh-contoh tersebut, dan memberikan semacam penutup ketika siswa telah mampu mendeskripsikan gagasan yang diajarkan oleh guru (Jacobsen, 2009). Dengan membiasakan siswa dalam kegiatan pemecahan masalah, diharapkan kemampuan siswa dalam menyelesaikan berbagai masalah akan meningkat.

Selain metode pembelajaran, hal lain yang tidak kalah penting dalam peningkatan mutu pendidikan adalah penilaian. Masih dijumpai kebanyakan guru dalam melakukan penilaian hasil belajar masih menggunakan penilaian konvensioal, mereka terjebak pada filosofi dan pendekatan lamanya, padahal dalam penilaian konvensional jarang menilai seluruh kemampuan siswa. Solusi untuk mengatasi kelemahan dari penilaian konvensional adalah dengan menggunakan penilaian alternatif atau penilaian autentik.

Secara konseptual penilaian autentik lebih bermakna secara signifikan dibandingkan dengan tes pilhan ganda terstandar sekalipun. Ketika menerapkan penilaian autentik untuk mengetahui hasil dan prestasi belajar peserta didik, guru menerapkan kriteria yang berkaitan dengan konstruksi pengetahuan, aktivitas mengamati, dan mencoba (Kemdikbud, 20I3). Penilaian autentik mampu menggambarkan peningkatan kemampuan representasi matematika siswa, baik dalam rangka mengobservasi, menalar, mencoba, membangun jejaring, dan lain-lain. Ada beberapa teknik penilaian yang dapat digunakan pada penilaian autentik, diantaranya adalah penilaian kinerja (performance assessment) dan penilaian proyek. Menurut Surapranata (2009), penilaian kinerja adalah teknik penilaian yang dilakukan pada saat 
proses pembelajaran berlangsung dan memungkinkan terjadinya praktek. Penilaian kinerja memerlukan pertimbangan-pertimbangan khusus. Pertama, langkah-langkah kinerja harus dilakukan peserta didik untuk menunjukkan kinerja yang nyata untuk suatu atau beberapa jenis kompetensi tertentu. Kedua, ketepatan dan kelengkapan aspek kinerja yang dinilai. Ketiga, kemampuan-kemampuan khusus yang diperlukan oleh peserta didik untuk menyelesaikan tugastugas pembelajaran. Keempat, fokus utama dari kinerja yang akan dinilai, khususnya indikator esensial yang akan diamati. Penilaian proyek adalah penilaian berbasis kelas terhadap tugas yang harus diselesaikan dalam waktu tertentu (Surapranata, 2007). Penilaian proyek mulai dilakukan dari pengumpulan, pengorganisasian, pengevaluasian, hingga penyajian data.

Proses pembelajaran yang dilaksanakan dengan menggabungkan antara metode pembelajaran dan penilaian autentik memberikan peluang besar kepada setiap siswa untuk lebih aktif sehingga dapat meningkatkan kemampuan representasi matematis dalam pembelajaran matematika. Hal ini juga, akan dapat berimplikasi pada hasil belajar matematika yang akan diperoleh siswa setelah mengikuti proses pembelajaran.

Berdasarkan kajian di atas, maka tujuan dari penulisan artikel ini adalah untuk mengetahui permasalahan yang berkaitan dengan metode pembelajaran, penilaian autentik, dan kemampuan representasi matematis pada siswa SMP Negeri 5 dan SMP Negeri 8 Kota Tidore Kepulauan.

\section{Metode Penelitian}

Metode yang digunakan dalam penelitian ini adalah metode eksperimen. Variabel penelitian terdiri atas variabel bebas dan variabel terikat. Adapun variabel bebasnya adalah metode pembelajaran dan penilaian autentik, sedangkan variabel terikatnya adalah kemampuan representasi matematis. Desain yang digunakan adalah desain faktorial $2 \times 2$ (faktorial post test only design) yang disajikan dalam Tabel $\mathrm{I}$.

Tabel I. Desain Eksperimen Faktorial $2 \times 2$

\begin{tabular}{|c|c|c|}
\hline \multirow{2}{*}{ Penilaian Autentik (B) } & \multicolumn{2}{|c|}{ Metode Pembelajaran (A) } \\
\hline & Penemuan Terbimbing $\left(A_{I}\right)$ & Ekspositori $\left(\mathbf{A}_{2}\right)$ \\
\hline Unjuk Kerja $\left(B_{I}\right)$ & $A_{1} B_{1}$ & $A_{2} B_{1}$ \\
\hline Proyek $\left(\mathrm{B}_{2}\right)$ & $A_{1} B_{2}$ & $A_{2} B_{2}$ \\
\hline
\end{tabular}

Populasi dalam penelitian ini adalah seluruh siswa kelas VIII semester 2 SMP Negeri 5 dan SMP Negeri 8 Kota Tidore Kepulauan pada tahun pelajaran 2015/2016, yaitu: sebanyak 4 kelas di SMP Negeri 5 Tidore Kepulauan dan 3 kelas di SMP Negeri 8 Kota Tidore Kepulauan. Sampel dalam penelitian ini dilakukan dengan menggunakan teknik cluster random sampling dan diperoleh sampel penelitian berjumlah 84 orang.

Uji Hipotesis dilakukan dengan Analisis Varian (ANAVA) dua arah dengan desain faktorial $2 \times 2$,
Uji lanjut dilakukan dengan menggunakan uji tDunnet, Sebelum uji hipotesis terlebih dahulu dilakukan uji persyaratan analisis yang terdiri dari: (I) uji normalitas dengan uji lilliefors; dan (2) uji homogenitas dengan menggunakan uji-bartlett (Kadir, 20I5).

\section{Hasil Penelitian dan Pembahasan}

Analisis statistik deskriptif data hasil penelitian disajikan pada Tabel 2 . 
Tabel 2. Analisis Statistik Deskriptif Data Hasil Penelitian

\begin{tabular}{cccccc}
\hline Variabel & Rerata & Modus & Median & Simpangan baku & Variansi \\
\hline$A_{1}$ & $72,57 I$ & 70 & 72,5 & 9,128 & 83,324 \\
\hline$A_{2}$ & $68,8 I$ & 60 & 70 & 10,213 & 104,303 \\
\hline$B_{1}$ & $68,8 I$ & 60 & 69 & 10,57 & 111,719 \\
\hline$B_{2}$ & 72,643 & 75 & 73 & $8,68 I$ & 75,357 \\
\hline$A_{1} B_{1}$ & 75,19 & 75 & 75 & 9,059 & 82,062 \\
\hline$A_{1} B_{2}$ & 69,952 & 70 & 70 & 8,623 & 74,348 \\
\hline$A_{2} B_{1}$ & 62,429 & 60 & 60 & 7,839 & $6 I, 457$ \\
\hline$A_{2} B_{2}$ & 75,333 & 75 & 75 & 8,058 & 64,933 \\
\hline
\end{tabular}

Pengujian hipotesis dalam penelitian ini menggunakan analisis varian (ANAVA) dua jalur. Analisis varian dua jalur digunakan untuk menguji pengaruh utama (main effect), interaksi (interaction effect), dan pengaruh sederhana (simple effect) antara metode pembelajaran dengan penilaian autentik. Hasil perhitungan disajikan pada Tabel 3.

Tabel 3. Hasil Analisis Varians Menggunakan ANAVA Dua Jalur

\begin{tabular}{|c|c|c|c|c|c|c|}
\hline Varians & JK & Db & RJK & $\mathbf{F}_{0}$ & $\mathbf{F}_{\mathrm{tab}}$ & Keterangan \\
\hline Antar A & 286.012 & I & 286.012 & 4.045 & 3.960 & Signifikan \\
\hline Antar B & 308.583 & 1 & 308.583 & 4.365 & 3.960 & Signifikan \\
\hline Interaksi & 1728.107 & I & 1728.107 & 24.443 & 3.960 & Signifikan \\
\hline Dalam & 5656.000 & 80 & 70.700 & & & \\
\hline Total & 7978.702 & 83 & & & & \\
\hline
\end{tabular}

Berdasarkan hasil perhitungan hipotesis, menunjukkan adanya interaksi antara metode pembelajaran dan penilaian autentik terhadap kemampuan representasi matematis, maka perhitungan dilanjutkan dengan formulasi tDunnet. Hasil perhitungan t-Dunnet disajikan pada Tabel 4.

Tabel 4. Ringkasan Hasil Uji Lanjut t-Dunnet

\begin{tabular}{cccc}
\hline Kelompok & $\mathbf{t}_{0}$ & $\mathbf{t}_{\text {tab }}$ & Keputusan \\
\hline $\mathrm{A}_{1} \mathrm{~B}_{1} \& \mathrm{~A}_{2} \mathrm{~B}_{1}$ & 4.918 & $\mathrm{I} .66$ & Tolak $\mathrm{H}_{0}$ \\
\hline $\mathrm{A}_{1} \mathrm{~B}_{2} \& \mathrm{~A}_{2} \mathrm{~B}_{2}$ & 2.074 & $\mathrm{I} .66$ & Tolak $\mathrm{H}_{0}$ \\
\hline $\mathrm{A}_{1} \mathrm{~B}_{1} \& \mathrm{~A}_{1} \mathrm{~B}_{2}$ & 2.019 & $\mathrm{I} .66$ & Tolak $\mathrm{H}_{0}$ \\
\hline $\mathrm{A}_{2} \mathrm{~B}_{1} \& \mathrm{~A}_{2} \mathrm{~B}_{2}$ & 4.973 & $\mathrm{I} .66$ & Tolak $\mathrm{H}_{0}$ \\
\hline
\end{tabular}

Temuan pertama penelitian ini dengan menggunakan teknik ANAVA dua jalur memperlihatkan bahwa ternyata $F_{\text {hitung }}=4,045$ lebih besar dari $F_{\text {tabel }}=3,960$ yang berarti menolak $H_{0}$. Dengan demikian, terdapat perbedaan rata-rata kemampuan representasi matematis siswa antara kelompok siswa yang menggunakan metode pembelajaran penemuan terbimbing dan kelompok siswa yang menggunakan metode ekspositori. Dari perbandingan dua metode ini, kemampuan representasi matematis memperlihatkan hasil yang lebih signifikan pada siswa yang diajar dengan metode penemuan terbimbing. Temuan ini juga didukung oleh penelitian yang dilakukan oleh Effendi (2012: 8), di mana pembelajaran dengan metode penemuan terbimbing lebih baik dari pada pembelajaran konvensional dalam peningkatan kemampuan representasi dan pemecahan masalah matematis. Metode penemuan terbimbing adalah cara menyajikan pelajaran yang memberikan kesempatan kepada 
siswa untuk menemukan informasi yang berupa konsep-konsep dan prinsip-prinsip dalam suatu proses mental, yang dilakukan melalui kegiatan percobaan dengan bimbingan dan petunjuk yang diberikan oleh guru. Pembelajaran matematika melalui metode ini melibatkan siswa secara aktif dengan menemukan sendiri baik teorema, rumus, maupun dalil, sedangkan guru hanya sebagai mediator ataupun fasilitator yang bertugas untuk menyediakan, membimbing, dan memenuhi kebutuhan siswa saat proses pembelajaran berlangsung. Sedangkan pada metode pembelajaran ekspositori, suasana kelas terkesan monoton sehingga menimbulkan kejenuhan siswa. Kemudian dalam proses belajar mengajar, interaksi antara siswa dengan siswa, siswa dengan guru kurang terjalin dengan baik. peran guru masih sangat dominan. Guru aktif menyampaikan materi, siswa mendengarkan. Setelah guru menyampaikan materi, siswa diberi tugas untuk mengerjakan soal baik itu secara individu maupun kelompok. Sebagai dampaknya, materi yang disampaikan guru kurang dikuasai dengan baik oleh siswa. Hal inilah yang mengakibatkan ratarata hasil kemampuan representasi matematis siswa pada kelompok yang diajar dengan metode penemuan terbimbing lebih tinggi daripada metode ekspositori.

Temuan kedua penelitian ini adalah hasil pengujian dengan menggunakan teknik ANAVA dua jalur juga memperlihatkan bahwa ternyata $F_{\text {hitung }}=4,365$ lebih besar dari $F_{\text {tabel }}=3,960$ yang berarti menolak $\mathrm{H}_{0}$. Dengan demikian, terdapat perbedaan rata-rata kemampuan representasi matematis siswa antara kelompok siswa yang diberi penilaian autentik bentuk unjuk kerja dan kelompok siswa yang diberi penilaian autentik bentuk proyek.

Berdasarkan hasil pengujian, diketahui bahwa penerapan penilaian autentik bentuk unjuk kerja lebih efektif bagi kemampuan representasi siswa. Penilaian autentik bentuk unjuk kerja ini menuntut siswa untuk lebih aktif dalam menyiapkan materi dengan baik, adanya umpan balik pada setiap tahapannya mendorong siswa untuk dapat menghasilkan sebuan karya yang maksimal. Dalam penilaian ini siswa dituntut untuk mendemonstrasikan penemuan ilmiah mereka, melakukan penalaran dan keterampilan dalam menyelesaikan tugas yang menarik dan menantang dalam konteks kehidupan sehari-hari sehingga dapat meningkatkan daya pikir dan kreativitas siswa dalam menyelesaikan masalah. Berbeda dengan penilaian autentik bentuk proyek, bentuk ini merupakan penilaian terhadap suatu tugas yang mencakup beberapa kompetensi dasar yang harus diselesaikan oleh siswa dalam periode waktu tertentu. Dalam pelaksanaannya, penilaian proyek membutuhkan proses yang lama, mulai dari perencanaan, pengumpulan data, pengorganisasian, pengolahan data, dan penyajian data sehingga tidak cukup waktu dalam menilai seluruh kemampuan siswa dalam kelas.

Temuan ketiga terdapat pengaruh interaksi antara metode pembelajaran dan penilaian autentik terhadap kemampuan representasi matematis siswa. Hal ini dapat dilihat dari hasil pengujian hipotesis dengan menggunakan formula ANAVA dua jalur memperlihatkan bahwa ternyata $F_{\text {hitung interaksi antara metode }}$ pembelajaran dan penilaian autentik sebesar 24,443 lebih besar daripada $F_{\text {tabel }}=3,960$. Hal ini berarti $\mathrm{H}_{0}$ ditolak. Dengan demikian, interaksi antara metode pembelajaran dan penilaian autentik mempunyai pengaruh yang sangat signifikan terhadap kemampuan representasi matematis siswa. Interaksi mengandung pengertian bahwa adanya kerjasama antara dua atau lebih variabel bebas dalam mempengaruhi variabel terikat. Signifikansi interaksi ini akan berimplikasi terhadap bentuk interaksi yang terjadi. Artinya, pengaruh interaksi akan mempunyai makna penting jika dilakukan pengujian efek-efek sederhana dari setiap tingkat perlakuan.

Temuan keempat dengan uji t-Dunnet diperoleh nilai $t_{\text {hitung }}=9,918$ lebih besar daripada $t_{\text {tabel }}=1,66$ yang berarti $\mathrm{H}_{0}$ ditolak. Artinya, secara signifikan terdapat perbedaan kemampuan representasi matematis antara siswa yang diajarkan dengan metode penemuan terbimbing dengan siswa yang diajar dengan metode ekspositori pada kelompok siswa yang diberi penilaian autentik bentuk unjuk kerja.

Temuan kelima terdapat perbedaan kemampuan representasi matematis siswa yang diberi metode pembelajaran penemuan terbimbing lebih rendah daripada siswa yang diajarkan dengan metode ekspositori bagi siswa yang mendapat penilaian autentik bentuk proyek. 
$\mathrm{Hal}$ ini sesuai dengan hasil perhitungan menggunakan uji $\mathrm{t}$-Dunnet diperoleh nilai $\mathrm{t}_{\text {hitung }}=$ 2,074 lebih besar daripada $t_{\text {tabel }}=1,66$ yang berarti $\mathrm{H}_{0}$ ditolak. Artinya, secara signifikan terdapat perbedaan kemampuan representasi matematis antara siswa yang diajar dengan metode penemuan terbimbing dengan siswa yang diajar dengan metode ekspositori pada kelompok yang diberi penilaian autentik bentuk proyek.

Temuan keenam hasil perhitungan dengan uji $\mathrm{t}$-Dunnet diperoleh nilai $t_{\text {hitung }}=5,347$ lebih besar daripada $t_{\text {tabel }}=1,66$ yang berarti $H_{0}$ ditolak. Artinya, secara signifikan terdapat perbedaan kemampuan representasi matematika antara siswa yang mendapat penilaian autentik bentuk unjuk kerja dengan siswa yang mendapat penilaian autentik bentuk proyek pada kelompok siswa yang diajarkan dengan metode penemuan terbimbing.

Temuan ketujuh kemampuan representasi matematis siswa yang mendapatkan penilaian autentik bentuk unjuk kerja lebih rendah daripada siswa yang diberi penilaian autentik bentuk proyek, bagi kelompok siswa yang diberi metode pembelajaran ekspositori. Hal ini sesuai dengan hasil perhitungan dengan menggunkana uji tDunnet diperoleh nilai $t_{\text {hitung }}=4,973$, lebih besar daripada $t_{\text {tabel }}=1,66$ pada taraf signifikan $\alpha=0,05$. Hasil perhitungan dengan formula ANAVA dua jalan juga menunjukkan perbedaan ini, di mana kelompok siswa yang diajarkan dengan metode ekspositori, sekor siswa dengan penilaian autentik bentuk unjuk kerja, yaitu: sebesar 68,8I lebih rendah dibandingkan sekor siswa dengan penilaian autentik bentuk proyek, yaitu: sebesar 72,57. Adanya kelompok pembanding berupa kelompok siswa yang diberi metode ekspositori dan diberi penilaian autentik bentuk unjuk kerja merupakan konsekuensi logis bahwa kemampuan representasi matematis yang dicapai memang pengaruh dari perlakuan.

\section{Kesimpulan}

Berdasarkan hasil pengujian hipotesis yang telah dilakukan maka dapat ditarik beberapa kesimpulan diantaranya adalah: Kemampuan representasi matematis siswa antara kelompok siswa yang diajar dengan menggunakan metode penemuan terbimbing lebih tinggi daripada kelompok siswa yang diajar dengan menggunakan metode pembelajaran ekspositori. Kemampuan representasi matematis siswa yang diberi penilaian autentik bentuk unjuk kerja lebih tinggi daripada kemampuan representasi matematis siswa yang diberi penilaian autentik bentuk proyek. Terdapat pengaruh interaksi antara metode pembelajaran dan penilaian autentik terhadap kemampuan representasi matematis siswa. Untuk kelompok siswa yang menggunakan metode penemuan terbimbing, kemampuan representasi matematis siswa yang diberikan penilaian autentik bentuk unjuk kerja lebih tinggi dibandingkan kemampuan representasi matematis siswa diberikan penilaian autentik bentuk proyek. Untuk kelompok siswa yang menggunakan metode ekspositori, kemampuan representasi matematis kelompok siswa yang diberikan penilaian autentik bentuk unjuk kerja lebih rendah daripada kelompok siswa yang diberikan penilaian autentik bentuk proyek. Kelompok siswa yang diberikan penilaian autentik bentuk unjuk kerja, kemampuan representasi matematis siswa yang diajarkan dengan metode pembelajaran penemuan terbimbing lebih tinggi dibandingkan kelompok siswa yang diajarkan dengan menggunakan metode ekspositori. Untuk kelompok siswa yang diberikan penilaian autentik bentuk proyek, kemampuan representasi matematis siswa yang diajarkan dengan metode pembelajaran penemuan terbimbing lebih rendah daripada kelompok siswa yang diajarkan metode pembelajaran ekspositori.

\section{Daftar Pustaka}

Bal Ayten Pinar. (20I5). "Skills of Using and Transform Multiple Representation of The Prospective Teachers." $7^{\text {th }}$ Word Conference on Educational Sciensces. Athene: Greece.

Eggen Paul, dan Don Kauchak. (20I2). Strategi dan Model Pembelajaran: Mengajarkan Konten dan Keterampilan Berpikir terjemahan Satrio Wahono. Jakarta: Indeks.

Hasibuan. H, Irwan dan Mirna. (20I4). Penerapan Metode Penemuan Terbimbing Pada Pembelajaran Matematika Kelas XI IPA SMAN I Lubuk Alung. Jurnal Pendidikan Matematika, 3(I): 38-44. 
Jacobsen A. David, Paul Eggen dan Donald Kauchak. (2009). Methods for Teaching Terjemahan Ahmad Fawaid \& Khoirul Anam. Yogyakarta: Pustaka Pelajar.

Kartini. (2009). Peranan Representasi Dalam Pembelajaran Matematika. Prosiding Seminar Matematika dan Pendidikan Matematika. $36 \mathrm{I}$.

Leo Adhar Effendi. (20I2). Pembelajaran Matematika Dengan Metode Penemuan Terbimbing Untuk Meningkatkan Kemampuan Representasi dan Kemampuan Pemecahan Masalah Matematis Siswa SMP. Jurnal Penelitian Pendidikan, 3(2): I-I0.
Kemendikbud. (II September 2013). Materi Sosialisasi Kurikulum 2013.” http://s2.hubimg .com.

Mailizar. (2 November 2015). PISA 20I3: Lessons for Indonesia. http://m.thejakartapost.com.

Napitupulu. (2 November 2015). Prestasi Sains dan Matematika Indonesia Menurun. http://edukasi.kompas.com. (diakses 2 November 2015).

Sumarna Surapranata. (2007). Panduan penulisan Tes tertulis. Bandung: Remaja Rosdakarya. 